\title{
Teachers' Involvement in Enhancing the Sports Potential of Students with Hearing Disabilities in Schools
}

Mohd Hanafi Mohd Yasin, Mohd Mokhtar Tahar, Suziyani Mohamad, Nur Anis Nasuha Ramli dan Rabaishah Azirun

To Link this Article: http://dx.doi.org/10.6007/IJARBSS/v11-i12/11953

DOI:10.6007/IJARBSS/v11-i12/11953

Received: 05 October 2021, Revised: 07 November 2021, Accepted: 28 November 2021

Published Online: 19 December 2021

In-Text Citation: (Yasin et al., 2021)

To Cite this Article: Yasin, M. H. M., Tahar, M. M., Mohamad, S., \& Azirun, N. A. N. R. dan R. (2021). Teachers' Involvement in Enhancing the Sports Potential of Students with Hearing Disabilities in Schools. International Journal of Academic Research in Business and Social Sciences, 11(12), 2347-2354.

Copyright: (c) 2021 The Author(s)

Published by Human Resource Management Academic Research Society (www.hrmars.com)

This article is published under the Creative Commons Attribution (CC BY 4.0) license. Anyone may reproduce, distribute, translate and create derivative works of this article (for both commercial and non0-commercial purposes), subject to full attribution to the original publication and authors. The full terms of this license may be seen

at: http://creativecommons.org/licences/by/4.0/legalcode

Vol. 11, No. 12, 2021, Pg. 2347- 2354

Full Terms \& Conditions of access and use can be found at http://hrmars.com/index.php/pages/detail/publication-ethics 


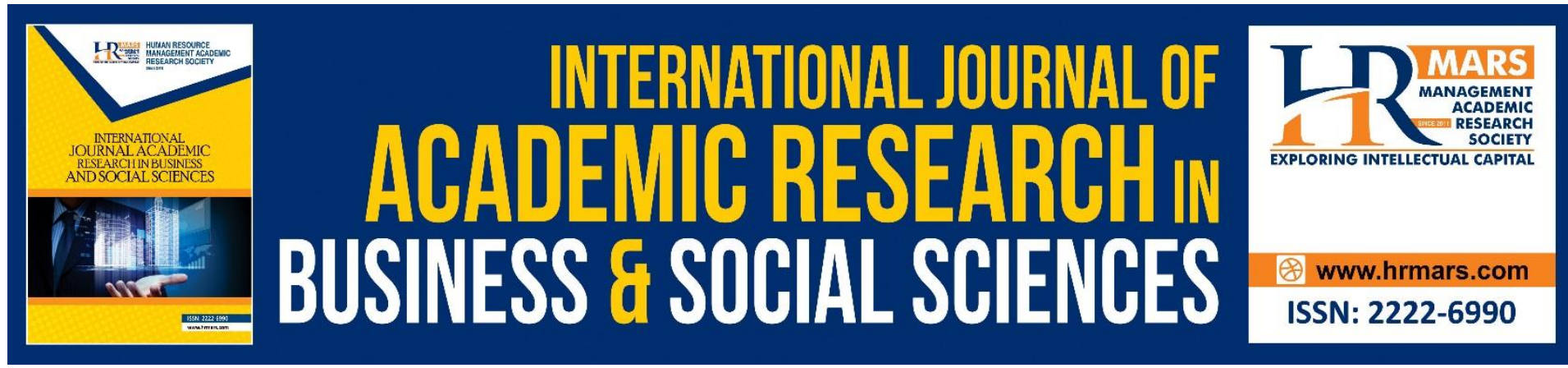

\title{
Teachers' Involvement in Enhancing the Sports Potential of Students with Hearing Disabilities in Schools
}

\author{
Mohd Hanafi Mohd Yasin, Mohd Mokhtar Tahar, Suziyani \\ Mohamad, Nur Anis Nasuha Ramli dan Rabaishah Azirun \\ Universiti Kebangsaan Malaysia, IPG Kampus Pendidikan Islam, Bangi
}

\begin{abstract}
This study aims to look at the approach of Hearing Disability's teachers in highlighting the potential of sports with Special Needs Students in schools throughout Malaysia and look at the challenges and obstacles faced by teachers and schools in highlighting sports opportunities for students with hearing disability. In addition, this study is also to see the types of sports that students are interested to participate in up to the highest level. This study has completed three Special Education hearing disability's teachers from various types and categories of schools throughout Malaysia to respond to the study. Data obtained through interview sessions held and analyzed using thematic methods. The findings of the study show that used by teachers, the role played by the school as well as the challenges and obstacles faced by teachers in highlighting the sports potential of these students with hearing disability. In conclusion, teachers and schools administration have used various types such as identifying the potential of students with hearing disability through Physical Education classes, 1 Murid 1 Sukan program, Co-curriculum Senior Assistant Teacher and good relation between schools. In addition, this study has also identified the types of sports that students with hearing disability more to the level such as representing the school in the Cross-Country event at the State level and competing with typical students. Finally, this study found that the challenges faced in highlighting the sports potential of students with hearing disability are parents and constraints in dividing time between academics and sports.
\end{abstract}

Keywords: Hearing Disability's Students, Sports Potential, Teachers' Involvement

\section{Introduction}

The involvement of teachers in highlighting the sports potential of students with special hearing needs in Malaysia was conducted to study the extent to which teachers are sensitive to the potential of students with special hearing needs in the field of sports. This study also examines the role played by teachers and schools in highlighting the potential of sports that have been highlighted by students with special hearing needs in Malaysia to advance their potential to a better place in sports. 
In addition, this study is also to identify each process and approach done by teachers in developing the sports talents of their students as well as refer to the responsible parties such as the District Education Office (PPD), State Education Department (JPN) and the Ministry of Education Malaysia ( $\mathrm{MOE}$ ) in developing sports among students with special needs to the school, district, state level and then the national level or higher level and compete with those who are at the same level of achievement. In addition, this study is to identify the cooperation and assistance provided by the National Sports Council (NSC) to teachers in developing the potential and sports talents of students with special hearing needs so that they are in the right place before going further in the field. this sport.

Next, this study was conducted to detect obstacles and challenges that exist throughout the process of teachers to develop the sports potential of students with hearing special needs in Malaysia to a higher level and together discuss ways or methods that can be done to overcome each challenge and obstacle and the path of students with special needs in the field of sports to the highest level, namely representing the Sports Association for the Deaf in the Malaysian Games for the Deaf (SOPMA) and then to the international level to represent countries such as the Asia-Pacific Deaf Games and Sports Deaflympic Games. The Malaysian Deaf Games or SOPMA is held every two years and this sport is an important sport for every state sports association to qualify their selected talented athletes to represent the country in the Asia-Pacific Deaf Games or the Deaf Olympics.

\section{Highlight the Sport Potential}

This study was conducted to collect effective approaches that have been done by teachers in highlighting the potential of hearing disability students' sport in schools so that they succeed and can represent Malaysia in various Deaf Sports Championships whether competed in Malaysia or abroad.

\section{Inspiration and Reference}

The role played by teachers in highlighting the sports potential of students in special need in Malaysia especially students with hearing disability who are interested in certain sports. Students with hearing disabilities who have been successful in their sports to the highest level can be seen from the way teachers highlight the potential of their sport to be applied to other students. In addition, this study was able to examine the various methods that have been used in highlighting the sports of students so that they can succeed in the field of sports and sports tendencies in special education schools of hearing impairment.

\section{School Management}

Identify school management in providing opportunities to students with hearing disability in participating in sports either representing classes in sport competitions on School Sports Day or representing schools in sports competitions between Special Education Schools throughout the district or state. The opportunity provided by the school is very important in developing students talents in sport because if the talents and potentials are only identified by teachers alone without action taken by school administration to further enhance their potential through organized by the Special Education sports division, their talents seems to be buried and Malaysia will lose talented athletes in certain sports to be sent to represent Malaysia at the most famous international sports events such as the Deaflympics Games where all deaf people with sports talent gather to show their skills and sports potential. 


\section{Method}

\section{Participants and Procedure}

The participants consisted of 4 teachers in special education, teaching hearing disability's students. These teachers come from different special education's school- primary school of special education in hearing disability, secondary school of special education in hearing disability, and inclusive programmes in school primary and secondary. In selecting participants, teachers who teach in special education schools with deaf students could be selected to respond to this research. These teachers should go through at least one interview session to answer all the questions related to how schools handle students with hearing disability in their sport potential or chance to grow up their potential in sport.

\section{Measures}

The instrument used in this study was an online interview with teachers from primary and secondary special education schools as well as teachers from special education programs inclusive of hearing specialization. The interview session began with the teacher's background including educational background and teaching experience. Next, the interview session continued with school information as well as sports tendencies in schools, especially among special education students with hearing impairments. In addition, the way teachers highlight the potential of student's sports and state the highest level of students in sports.

\section{Data Analysis}

The analysis used in obtaining results to this data is thematic analysis. This analysis is used to obtain data related to the involvement of teachers in highlighting the sports potential of students with hearing impairments in Malaysia. This analysis is very suitable to know the approach used in identifying students who have sports potential and the role played by the school administration to ensure that students' sports potential is highlighted. Therefore, this method is used in identifying the approach and role played by the administration in identifying potential students more clearly.

\section{Result}

Analysis of Teachers' Involvement in Enhancing the Sports Potential of Students with Hearing Disabilities in Schools

In line with the main objectives of teachers in highlighting the sports potential of students with hearing impairments in Malaysia, is to identify the approach of Special Education teachers and the involvement of schools, especially the administration in highlighting the sports potential of students with hearing disabilities. In addition, the objective of this study is also to find out the sports that students participate in and represent the school to the highest level. Finally, the challenges and obstacles of teachers/school administration in highlighting the potential of hearing students' sports in schools. 
INTERNATIONAL JOURNAL OF ACADEMIC RESEARCH IN BUSINESS AND SOCIAL SCIENCES Vol. 11, No. 12, 2021, E-ISSN: 2222-6990 @ 2021 HRMARS

\begin{tabular}{|c|c|c|c|}
\hline & Gender & Age & Types of school \\
\hline Respondent 1 & Woman & 37 y/o & $\begin{array}{l}\text { Primary school of special } \\
\text { education. }\end{array}$ \\
\hline Respondent 2 & Woman & 33 y/o & $\begin{array}{l}\text { Special education programs } \\
\text { inclusive of primary school. }\end{array}$ \\
\hline Respondent 3 & Woman & $44 \mathrm{y} / \mathrm{o}$ & $\begin{array}{l}\text { Special education programs } \\
\text { inclusive of secondary school. }\end{array}$ \\
\hline Respondent 4 & Man & 29 y/o & $\begin{array}{l}\text { Secondary school of special } \\
\text { education }\end{array}$ \\
\hline
\end{tabular}

Table 1 Respondents Profile

\begin{tabular}{|l|l|l|l|l|l|}
\hline \multicolumn{2}{|c|}{ R= Respondent } \\
\hline $\begin{array}{l}\text { Teachers' approach in enhancing the sports potential of students with hearing } \\
\text { disability }\end{array}$ & R1 & R2 & R3 & R4 \\
\hline $\begin{array}{l}\text { Through physical education and health education } \\
\text { subject }\end{array}$ & & & & \\
\hline Join the 1 Sport 1 student programme & & & & \\
\hline $\begin{array}{l}\text { The role of school administration in enhancing the sports potential of students hearing } \\
\text { disability in school }\end{array}$ & & & & \\
\hline The role of senior co-curricular teacher & & & $/$ & \\
\hline Good relationship among school of special education & & & & \\
\hline
\end{tabular}

Table 2 Methods of highlighting the potential of sport

Through the interviews, there are differences in the approaches used by teachers in highlighting the potential of students' sports. Nevertheless, their purpose is the same, to provide equal opportunities to special education students in sports. In addition, the differences in terms of teacher approaches are due to differences in the type of school as well as the school environment and background of students. But, from the interview, teachers usually capture students' potential in sport from their lessons in physical and health 
education and many more sports' event that the school organizes throughout the year. From the activities in teaching and learning sessions, teachers easily got their potential in certain sports or through their skill in doing activities also their stamina which is suitable in certain sports. From that, teachers offered them to be involved in sports or suggested that they take a place in a few sports before getting the most suitable ones. The school also has their own target for students whether in academic or co-curricular, so that the administration has variety in order to highlight students' potential in sports.

\section{The Challenge in Highlighting Students with Hearing Disabilities in Sports}

In this research, the challenge that teachers' face was varied and the most challenging was to get trust from their parents in getting their kids in sports that they were interested in. Most parents are too scared that their kids get injured during training sessions and tournaments.

\begin{tabular}{|l|l|l|l|l|l|}
\hline \multicolumn{2}{|l|}{} & R1 & R2 & R3 & R4 \\
\hline $\begin{array}{l}\text { Challenges in understanding the sports potential of students with hearing disability in } \\
\text { school }\end{array}$ & & & & \\
\hline Parental barrier to participating in sports & & & & \\
\hline Problem of lack of students in school & & & & & \\
\hline Time management between academic and sport & & & & & \\
\hline
\end{tabular}

Table $3 \quad$ The challenge in highlighting students' potential in sports

Challenges from the aspect of barriers from parents who are not confident in their children's ability and safety, lack of students for a special education school with hearing disabilities and time constraints between academics and sports are the reasons why teachers can not highlight the potential of hearing students in school even they have good skills and potential in sports. Because of these challenges, professional athletes from a particular sport for a deaflympic event may experience problems. This is because, this constraint has been the main cause of the lack of skilled athletes for a sport to be sent to represent the next state of Malaysia to the highest level.

\section{Types of Sport which Special Education Students with Hearing Disability Participated in until the Highest Level}

The type of sports that special education students with hearing disability engage in is influenced by the factors of the school environment and the category of the school, whether urban or rural. Rural schools are more inclined in outdoor sports which are played on fields such as football, rugby and elsewhere while urban schools are more active in track and indoor sports. However, this factor can change due to the influences or interest of a student in a sport. For example a special education student with hearing disability who lives in a rural area but idolizes Nicol David who is a national squash player. The student has been inclined 
towards indoor sports even though the school does not have facilities for the game of squash and the student has other initiatives by taking private classes for this game.

\begin{tabular}{|l|l|l|l|l|l|}
\hline \multicolumn{2}{|l|}{} & R1 & R2 & R3 & R4 \\
\hline \multicolumn{2}{|l|}{ Types of sport which students participated in until the highest level. } \\
\hline Sports on track & & $/$ & & \\
\hline Indoor sports & & & & \\
\hline Outdoor sports & & & & \\
\hline Cross- country & & $/$ & & \\
\hline
\end{tabular}

Table 4

Types of sport which special education students with hearing disability participated in until the highest level.

\section{Conclusion}

Potensi sukan pelajar kurang upaya pendengaran harus mendapat perhatian sama seperti pelajar biasa dan pelajar kurang upaya pendengaran juga perlu diberi peluang yang adil dalam bidang sukan yang mereka minati. Pendekatan dan peranan guru dan juga pihak pentadbiran sekolah memberi kesan yang baik dalam mengembangkan sukan di kalangan pelajar yang mempunyai masalah pendengaran di Malaysia ke tahap tertinggi. Di samping itu, pendekatan guru dalam mengetengahkan potensi murid bermasalah pendengaran di sekolah melalui kelas Pendidikan Jasmani dan Pendidikan Kesihatan dan program 1 pelajar 1 Sukan adalah pendekatan terbaik. Guru Pendidikan Khas bermasalah pendengaran menyumbang kepada perkembangan sukan Pekak di Malaysia dengan mencungkil bakat dan potensi sejak sekolah.

Di samping itu, peranan yang dimainkan oleh Guru Kokurikulum Kanan dan melalui hubungan baik antara sekolah juga memberi kesan positif dalam usaha menonjolkan potensi sukan pelajar pendengaran dan pada masa yang sama mengembangkan sukan di kalangan pelajar pendengaran. Kepelbagaian kemahiran sukan yang ditunjukkan oleh pelajar pendengaran memberikan harapan positif terhadap masa depan sukan di kalangan Pekak di Malaysia. Pelajar kurang upaya pendengaran di Malaysia memberi respons yang baik terhadap program sukan yang dianjurkan oleh Bahagian Pendidikan Khas Negeri dalam menyertai kejohanan yang diadakan sepanjang tahun dan pencapaian yang ditunjukkan oleh pelajar pendengaran setiap tahun sangat memberangsangkan. 


\section{References}

Ahmad, A. H. (2012). Mengenal dan Menangani Orang Kurang Upaya. Kuala Lumpur: Dewan Bahasa dan Pustaka.

Bernama. (2016). Jadikan SOPMA Platform baiki Prestasi Atlet. Astro Awani. 30 September. Boyatzis, R. E. (1998). Transforming Qualitative Information; Thematic Analysis and Code Development. London: Sage Publication.

Buku Maklumat Pendidikan Khas. (2007). Kementerian Pelajaran Malaysia.

Piaw, C. Y. (2014). Kaedah Penyelidikan (3rd ed.). Mc Graw Hill Education (Malaysia) Sdn.Bhd. hlm.39-140.

Hartman, E., Houwen, S., Vissher, C. (2011). Motor Skill Performance and Sport Participation in Dear Elementary School Children. Adapted Physical Activity Quarterly 28, 132-145. University of Groningen, The Netherlands.

Hallahan, D. P., Kauffman, L. (2006). Exceptional Learners. Introduction to special Education. Horejes, T. D. (2012). Social Constructions of Deafness: Examining Deaf Languacultures in Education. Washington, DC: Gallaudet University Press.

Sobro, I. (2015). An innovative method of managing the training process of qualified basketball players with hearing impairment. Journal of Physical Education and Sports, 15(4), 640-645.

Kementerian Pendidikan Malaysia. (2003). Kurikulum Bersepadu Sekolah Rendah. Kuala Lumpur: Dewan Bahasa dan Pustaka.

Kementerian Pendidikan Malaysia. (2011). Kurikulum Bersepadu Sekolah Rendah. Kuala Lumpur: Dewan Bahasa dan Pustaka.Laman Rasmi Persatuan Sukan Orang Pekak Malaysia. http://www.msdeaf.org.my/

Marschack, M., \& Lang, H.G. (2002). Educating deaf students. New York: Oxford University Press.

Merriam, S. B. (2002). Qualitative research in practice: Example for discussion and analysis. San Francisco: Jossey-Bass

Mrizalar. (2020). SOPMA (2020) Tarik Penyertaan. Sukan Malaysia. 31 Januari. https://www.sukanmalaysia.my/

Kurkova, P., Nanci, A. S. (2016). Communication strategies used by physical education teachers and coaches in residential schools of the deaf in the US. Acta Facultatis Educationis Physicae Universitatis Comenianae, 36(1).

Arsici, R., Slavnic, S., Kovacevic, J. (2012). Sport Activities as a Factor in Socialization of Deaf Students. Journal of Physical Education and Sport. University of Belgrade, Serbia.

Hoe, W. E. (1995). Penghargaan Pendidikan Jasmani dan kesihatan. Edisi Kedua. 